\title{
GERAKAN PEMBARUAN TASAWUF DI INDONESIA
}

\author{
Sulaiman Al-Kumayi \\ INSTITUT AGAMA ISLAM NEGERI (IAIN) WALISONGO \\ SEMARANG \\ e-mail: alkumayi97@yahoo.co.id
}

\begin{abstract}
This article aims to elaborate on Sufism reform movement in Indonesia. There former of Islam in Indonesia realize that Sufism is an integral part of Islam, therefore they are not hostile to Sufism, but tends to purify the Sufism of deviant practices. Irregularities which they saw in the midst of the Muslim community but claimed as part of Sufism must be cleaned. Sufism must be free of elements of heresy or shirk that could tarnish the purity of Islam. In this article, the author presents the figure of Hamka as a representation of Sufism reform movement in Indonesia. Although Hamka very appreciative, even followers of Sufism, he was never affiliated to the sufi order schools anywhere in the world.He also never made a separate congregation flow, as was common in the realm of the sufi order.
\end{abstract}

\begin{abstract}
Abstrak: Artikel ini bertujuan untuk mengelaborasi gerakan pembaruan tasawuf di Indonesia. Para pembaru Islam di Indonesia menyadari bahwa tasawuf merupakan bagian integral dalam Islam, karena itu mereka tidak memusuhi tasawuf, tetapi cenderung untuk memurnikan tasawuf dari praktik-praktik yang menyimpang. Penyimpangan yang mereka lihat di tengah-tengah masyarakat Muslim tetapi diklaim sebagai bagian dari ajaran tasawuf haruslah dibersihkan. Tasawuf harus terbebas dari unsur-unsur bid'ah atau syirik yang dapat menodai kemurnian ajaran Islam. Dalam artikel ini, penulis menyajikan sosok Hamka sebagai representasi dari gerakan pembaruan tasawuf di Indonesia. Sekalipun Hamka sangat apresiatif, bahkan pengamal tasawuf, ia tidak pernah berafiliasi ke aliran tarekat mana pun di dunia ini. Ia juga tidak pernah membuat aliran tarekat tersendiri, sebagaimana lazimnya dalam dunia tarekat.
\end{abstract}

Keywords: neo-sufisme, bid'ah, al-Quran, al-Sunnah, tarekat.

TEOLOGIA, VOLUME 24, NOMOR 2, JULI-DESEMBER 2013 
SULAIMAN AL-KUMAYI: Gerakan Pembaruan...

\section{A. Pendahuluan}

Gerakan pembaruan tasawuf-sebagaimana di bidang-bidang lainnya dalam ranah pemikiran Islam-dapat dilacak pada abad XVIII. Abad ini biasanya dianggap sebagai zaman kegelapan (dark age) dunia Islam, masa kemunduran politik, ekonomi, dan budaya di tiga negara Islam besar: Imperium Usmani, Safawiyyah Iran, dan Mughal India. ${ }^{1}$ Marshal G. Hodgson menggambarkan abad tersebut sebagai berikut:

Though the eighteenth century was not without its interesting and creative figures, it was probably the least notable of all in achievement of high-cultural excellence; the relative barrenness was practically universal in Muslim lands. ${ }^{2}$

Meskipun abad XVIII bukan tanpa mempunyai tokoh-tokoh yang menarik dan kreatif, mungkin masa itu merupakan titik terrendah dalam hal pencapaian peradaban; kemandulan relatif secara praktis universal di wilayah-wilayah Islam.

Meskipun demikian, menurut Elizabeth Sirriyeh ${ }^{3}$, dari sudut pandang agama dan khususnya dari sudut pandang tradisi spiritual sufi, masa tersebut tidak seluruhnya suram dan mandul. Terdapat sebuah kesadaran yang tersebar tentang terjadi kemerosotan dan keprihatinan terhadap pendangkalan makna sufisme di tengah masyarakat, yang tenggelam dalam takhayul dan terpesona oleh pengakuan-pengakuan luar biasa dari para ahli klenik.Tetapi kesadaran ini juga mendorong upaya reformasi yang penuh semangat, baik dari individu-individu ataupun gerakan-gerakan, yang mencapai momentumnya pada abad XIX.Upaya-upaya seperti ini kemudian berkembang lebih jauh menjadi revitalisasi spiritualitas Islam di daerah-daerah pusat Islam. Mereka juga berusaha untuk menyebarkan agama ke daerah-daerah di sekeliling mereka yang Islamnya dangkal, dan, dalam beberapa kasus, ke daerah-daerah yang belum terjangkau: Gurun Sahara Afrika Selatan, Asia Tenggara, perbatasan utara Kaukasus, Asia Tengah, dan menyeberang sampai ke Cina. ${ }^{4}$ 
SULAIMAN AL-KUMAYI: Gerakan Pembaruan...

Ditambahkan oleh Sirriyeh, bahwa gerakan pembaruan keagamaan (religious renewal) sebagian besar dilakukan oleh kaum sufi sendiri, baik oleh syekh-syekh terpelajar yang terkenal karena prestasi intelektualnya dalam bidang ilmu Islam lainnya, atau syekhsyekh yang semata-mata terkenal karena pengabdian mereka di dalam kehidupan spiritual, atau bahkan dari anggota-anggota biasa tarekat-tarekat sufi yang mendukung reformasi. Akan tetapi, kadangkadang ketidakpuasan karena penyimpangan-penyimpangan sufisme telah sedemikian dalamnya sehingga mereka menganggap reformasi tarekat-tarekat sufi bukan solusi yang dapat diterima. Karena itu, muncullah anti-Sufi yang keras, dengan bentuknya yang paling masyhur dalam gerakan kaum Wahhabi Arab yang terorganisir, pelopor ideologis bagi banyak Muslim modern penentang Sufi. ${ }^{5}$

Di sini, timbul pertanyaan: mengapa sufisme sedemikian rupa dibenci sehingga menimbulkan gerakan anti-Sufi seperti diperlihatkan oleh kaum Wahhabi atau gerakan modernis belakangan?

Menurut A.J. Arberry, kritik terhadap tasawuf atau sufisme disebabkan oleh adanya praktik-praktik yang melanggar syari'ah, immoralitas yang terbuka, dan oportunisme yang curang. Ditambahkan Arberry bahwa ilmu gaib (witchcraft) telah menggeser kedudukan rasio dengan tujuan yang telah dipertimbangkan baik-baik, yakni untuk menipu dan mengeksploitasi massa yang bodoh. Ia menggambarkan lebih jauh:

Every village or group of villages acquired its local saint, to be supported and revered during his lifetime, worshipped and capitalized after his death. Few indeed were the voices that dared protest against this ruinous order of things, for politician and theologian alike feared to oppose the true masters, and found it easier and more profitable to share in the swindle. ${ }^{6}$

Setiap desa atau sekumpulan desa mempunyai orang suci (wali) lokal yang didukung dan dipuja sepanjang hidupnya dan disembah serta diagung-agungkan setelah wafatnya.Hanya ada sedikit suara yang berani menentang tatanan yang buruk ini, karena politisi dan teolog tampaknya takut untuk menentang syekh-syekh sejati ini dan lebih mudah serta lebih

TEOLOGIA, VOLUME 24, NOMOR 2, JULI-DESEMBER 2013 
SULAIMAN AL-KUMAYI: Gerakan Pembaruan...

menguntungkan bagi mereka untuk bersama-sama terlibat di dalamnya.

Dalam perkembangannya, pemujaan wali ini menjadi ritual sehingga menziarahi makam-makam mereka dan berwasilah kepada mereka dianggap sebagai bagian dari 'ibadah' itu sendiri. Hamka dalam bukunya Pelajaran Agama Islam memberikan gambaran senada dengan Arberry. Katanya:

Dari masa ke masa timbullah dalam Dunia Islam penghormatan yang sangat berlebih-lebih kepada kubur orang yang telah mati. Berduyunlah orang 'awam pergi ziarah ke kubur-kubur yang dipandang keramat. Di sana mengadakan apa yang dinamai haul. Apabila ada yang sakit atau mengandung cita dan hajat, lalu bernazarlah dia, apabila citanya tercapai dia akan ziarah ke kubur itu membawa hadiah bahkan ada juga yang ber'itikaf dalam pekarangan kubur itu, sehingga di negeri Mesir adalah beberapa kubur yang ditentukan setiap tahun orang berkumpul ke sana beramai-ramai, persis seperti pasar malam. Bukan saja di Mesir, bahkan rata-rata di seluruh negeri Islam pergi ke kubur syekh Fulan tujuh kali berturut-turut, niscaya akan samalah pahalanya dengan naik haji satu kali. ${ }^{7}$

Pemujaan wali yang sangat berlebihan tersebut memang menimbulkan keprihatinan bagi segelintir tokoh Islam pada masa itu. Seorang penyair terkemuka, al-Badr al-Hijāzī misalnya, dengan nada yang sangat pedas mengkritik prakti-praktik semacam itu:

Kita tidak hidup untuk melihat setiap orang gila yang diangkat oleh para pengikutnya sebagai seorang Quthb.

Para ulama mereka berlindung kepadanya, mereka bahkan mengangkatnya sebagai Tuhan, menggantikan Tuhan yang ada di Tahta-Nya,

Karena mereka melupakan Allah, mereka mengatakan, "Dia menawarkan kebebasan dari penderitaan bagi seluruh umat manusia."

Ketika dia wafat, mereka menjadikannya tujuan ziarah dan mengeramatkannya, baik orang-orang Arab maupun non-Arab, semua sama saja,

Sebagian orang menciumi makamnya, ambang pintunya, dan debu-debunya. ${ }^{8}$ 
SULAIMAN AL-KUMAYI: Gerakan Pembaruan...

Dari beberapa kritik yang muncul terhadap praktik-praktik sufisme pada abad XVIII, yang paling tajam datang dari Muhammad Abd al-Wahhab (1703-1787).Ia melihat rusaknya tauhid umat Islam yang dirusak oleh ajaran-ajaran tarekat yang semenjak abad XIII memang tersebar luas di dunia Islam. Di tiap negara Islam yang dikunjunginya, Muhammad Abd al-Wahhab melihat kuburankuburan syekh tarekat bertebaran. Tiap kota, bahkan juga kampungkampung, mempunyai kuburan syekh atau wali masing-masing. Ke kuburan-kuburan itu umat Islam pergi naik haji dan meminta pertolongan syekh atau wali yang dikuburkan di dalamnya untuk menyelesaikan problema hidup mereka sehari-hari.Ada yang meminta supaya diberi anak, ada pula yang meminta supaya diberi jodoh, ada yang meminta supaya disembuhkan dari penyakit yang dideritanya dan ada pula yang meminta supaya diberi kekayaan.Dari sini, Abd al-Wahhab berkesimpulan bahwa praktik ini sangat menyimpang dari ajaran tauhid.Ini adalah bentuk penyembahan berhala dan termasuk perbuatan syirik.9 Ia menganggap ini sebagai bentuk jahiliah baru, bahkan lebih gelap dan lebih bobrok dibanding jahiliah pada masa pra-Islam. ${ }^{10}$

Sebenarnya, kritik-kritik terhadap sufisme muncul juga dari dalam sufisme itu sendiri. Hal ini seperti yang termaktub dalam sebuah surat dari seorang syekh terkemuka, Ahmad bin Idrīs (17601837), yang ditujukan kepada muridnya yang berkelana ke Sudan. Ia memperingatkan sang murid tentang bahaya orang-orang awam yang ada di sekitarnya terhadap keadaan ( $h \bar{a} l)$ spiritualnya:

Ketahuilah anakku, bahwa orang-orang di zamanmu, meskipun kelihatannya mereka memujimu, namun sebenarnya mereka adalah orang yang mudah putus asa, dan hal ini tidak akan membawa keuntungan bagi mereka di hadapan Allah. Allah, yang Maha terpuji dan Mahaagung, telah memerintahkan kepada Nabi-Nya bersabar dengan: “....(yakni) orang-orang yang berdoa kepada Tuhannya di pagi dan petang karena menghendaki perjumpaan dengan-Nya (QS. al-Kahfi [18]: 28). Persahabatan dengan rakyat jelata yang tidak mengharapkan ridha Allah dan Nabi-Nya adalah racun yang mematikan, yang

TEOLOGIA, VOLUME 24, NOMOR 2, JULI-DESEMBER 2013 
SULAIMAN AL-KUMAYI: Gerakan Pembaruan...

sewaktu-waktu dapat merusak agama mereka kecuali jika Allah menjaganya.Maka berhati-hatilah terhadap orang-orang di zamanmu itu karena mereka tidak ikhlas mencintai Allah.Dan semoga Allah menjagamu dari orang-orang itu. ${ }^{11}$

Surat ini menunjukkan bahwa Syekh Ahmad ibn Idrīs memandang rendah kebanyakan kaum sufi Afrika, meskipun dia juga mengakui adanya orang-orang yang benar-benar saleh di antara kaum sufi Sudan.

Di Afrika Utara, perasaan yang sama diekspresikan oleh seorang sufi semasa Ahmad ibn Idrīs, yaitu Ahmad al-Tijānī (1737-1815), dalam suratnya kepada salah seorang muridnya di Fez: "Ketahuilah bahwa tidak seorang pun sekarang ini yang bisa terhindar dari dosa, karena dosa mengguyur manusia seperti hujan lebat." Dalam peristiwa yang lain dia meratap: "Zaman sekarang ini adalah zaman di mana pondasi ajaran ilahi telah hancur...; dan itu di luar kemampuan siapa pun untuk melaksanakan perintah Allah dalam setiap keadaan dan waktu pada masa sekarang..."12

Suasana masa itu didominasi nuansa kekelaman, karena dalam pandangan kaum reformis, orang-orang awam telah gagal meraih kesejatian spiritualitas. Gambaran ini tidak segelap yang dilukiskan oleh kaum Wahhābī, tetapi cukup hitam karena dianggap sangat jarang ditemukan pencerahan, zaman ini adalah zaman penuh dosa dan masyarakat yang tidak tercerahkan tersebut merupakan beban berat karena ketidakmampuan mereka menggapai idealita-idealitas sufi. $^{13}$

Kritikan terhadap sufisme berlanjut pada abad XIX melalui tokoh utamanya, Sayyid Jamāl al-Dīn al-Afghānī al-Asadabādī (1838-1897). Menurut al-Afghānī, kaum sufi pada masanya itu adalah para pemimpin religius tradisional yang bertanggung jawab atas kemunduran umat Islam. Mereka gagal dalam beberapa hal; mereka melakukan interpretasi yang salah tentang Islam yang jauh dari sifatnya yang murni, dan menentang rasio; mereka mendorong sikap fatalis atas takdir Tuhan, suatu sikap yang menyebabkan ketidaktifan 
SULAIMAN AL-KUMAYI: Gerakan Pembaruan...

dan bahkan kemalasan serta menghilangkan sikap yang produktif; mereka mengikuti syekh-syekh mereka dalam semangat ketaatan dan taklid yang buta, yang merusak kemampuan kreatif dan pemikiran bebas mereka. Ia juga mengajak umat untuk menolak seluruh bentuk yang negatif dan jelek dari kepercayaan dan praktik masyarakat yang diciptakan kaum sufi pada akhir abad XIX, meskipun mereka tidak dikritik secara langsung, tetapi hanya dengan kritikan secara umum.

\section{B. Pembaruan Tasawuf di Indonesia}

Para ahli menjelaskan bahwa pemikiran tasawuf di Indonesia (baca: Nusantara), bermula dari dakwah Islam yang dilakukan oleh wali songo (wali sembilan). Menurut Prof. Abu Bakar Aceh, tasawuf yang berkembang di Indonesia sangat dipengaruhi oleh jalur masuknya agama ini, yakni tidak langsung dari tanah Arab tetapi melalui Persia dan India yang dibawa oleh para pedagang atau mereka yang khusus datang untuk menyiarkan agama Islam. Berkenaan dengan ini, Abu Bakar Aceh menulis:

Jika kita memperhatikan, bahwa agama Islam itu masuk ke Indonesia sekitar abad keempat dan kelima Hijrah, maka tak dapat tidak paham-paham sufi dan tasawuf yang sedang tersiar luas dan mendapat perhatian umum dalam negara-negara Islam ketika itu, terbawa pula bersama-sama ajaran Islam ke Indonesia. Maka lalu masuklah kemari paham wihdatul wujud menurut tafsiran Junaid dan Hallaj di samping ajaran Islam yang sebenarnya mengenai persoalan itu. Dalam sejarah wali songo kita dapati Syekh Siti Jenar yang mempertahankan pendirian fana dan kesatuan antara Khalik dan makhluk, yang dinamakan ittihad, di samping Sunan Kalijaga yang mempertahankan pendirian ahli sunnah bersama dengan wali-wali yang lain, lalu mengambil tindakan terhadap Syekh Siti Jenar itu. Kita lihat pula, bahwa di Aceh Hamzah Fansuri menyiarkan paham bersatu dengan Tuhan itu, disamping Abdur Ra'uf Singkil yang menyiarkan paham Islam yang sebenarnya untuk membasmi paham ittihad dalam ketuhanan itu, yang dianggapnya sesat dan menyesatkan. ${ }^{14}$

TEOLOGIA, VOLUME 24, NOMOR 2, JULI-DESEMBER 2013 
SULAIMAN AL-KUMAYI: Gerakan Pembaruan...

Menurut Azyumardi Azra, secara umum Islam tasawuf tetap unggul pada tahap pertama islamisasi di nusantara, setidaknya sampai akhir abad ke-17. Unggulnya Islam tasawuf ini dilatorbelakangi oleh fakta bahwa Islam tasawuf dalam beberapa segi "cocok" dengan latar belakang masyarakat setempat yang dipengaruhi asketisme Hindu-Buddha dan sinkretisme kepercayaan lokal. Juga terhadap fakta bahwa tarekat-tarekat sufi mempunyai kecenderungan bersikap toleran terhadap pemikiran dan praktek tradisional semacam itu, yang sebenarnya bertentangan dengan praktek ketat unilitarianisme Islam. ${ }^{15}$

Di setiap wilayah di mana pun Islam berkembang, baik pada level kerajaan maupun masyarakat, sufisme senantiasa mewarnai secara keseluruhan gambaran Islam yang muncul. Hal ini tidak terlalu mengherankan jika mempertimbangkan teori Islamisasi A.H. Johns (1961), seorang ahli Islam di Asia Tenggara, yang menjelaskan bahwa, khususnya sejak abad XIII, para guru sufilah yang paling banyak mempengaruhi jalannya Islamisasi di Nusantara.

Johns menegaskan bahwa Islam tidak dapat, dan tidak akan pernah bisa, menancapkan akarnya secara kuat di kalangan penduduk Nusantara, bahkan mungkin juga tidak dapat mengislamkan para penguasa, jika tidak disiarkan secara massif oleh para sufi. Ini tentu saja berkait erat dengan karakteristik sufisme itu sendiri yang cenderung lentur dalam menyikapi berbagai kepercayaan dan praktik keagamaan lokal, yang saat itu masih kuat dipengaruhi tradisi dan praktik kepercayaan pra-Islam. Di antara aspek-aspek ajaran lain, seperti fikih misalnya, sufisme merupakan bagian dari ajaran Islam yang paling sejalan dengan adaptasi budaya lokal. Hal ini karena sufisme lebih menekankan praktik-pratik meditasi untuk mencapai "derajat kesatuan" dengan Tuhan--yang dianggap sebagai bentuk kesempurnaan dalam beragama-ketimbang praktikpraktik keagamaan yang ditentukan syariah (fiqh). Dalam konteks Nusantara, lebih-lebih di Jawa, sufisme sedemikian mudah diterima masyarakat. Sufisme dalam banyak aspek memang sejalan dengan 
SULAIMAN AL-KUMAYI: Gerakan Pembaruan...

praktik-praktik dan pandangan dunia keagamaan masyarakat Jawa yang Hindu-Budhis. Oleh karena itu, A.H. Johns, berkesimpulan bahwa sufisme menduduki satu kategori penting dalam sejarah Islam di Nusantara. ${ }^{16}$

Pandangan Johns ini memang sejalan dengan fakta bahwa masa ketika Islam mulai mendapatkan tempat di masyarakat Nusantara, khususnya sejak abad XIII, sufisme bersama dengan lembaga tarekat tengah berjaya dalam wacana intelektual keagamaan di dunia Muslim. Nama-nama seperti AbūḤāmid al-Ghazālī (w. 1111), Abd alQadīr al-J̄ilanī (w. 1166), Ibn 'Arabī (w. 1240), adalah para sufi terkenal yang hidup --seperti bisa dilihat dari tahun wafatnya-dalam bentang waktu sejarah yang berdekatan dengan masa berlangsungnya proses Islamisasi di Nusantara. Begitu pula dari zaman sejarah yang sama kita juga mengenal nama-nama seperti Najm al-Dīn al-Kubrā (w. 1221) dan Abū Hasan al-Syadzīlī (w. 1258)--masing-masing pendiri tarekat Kubrawiyah dan Syadziliyah di Asia Tengah dan Afrika Utara-- serta nama-nama sufi lain yang sangat dikenal di dunia Islam.

Menurut Oman Fathurahman dan Jajat Burhanudin ${ }^{17}$, bila kita mulai dengan dunia Melayu, tradisi sufisme sudah terlihat bahkan dalam teks-teks klasik seperti Hikayat Raja-Raja Pasai dan Sejarah Melayu yang telah disebut di atas. Penggambaran konversi keislaman raja-raja Melayu melalui mimpi bertemu dengan Nabi Muhammad Saw--seperti dijelaskan dalam dua teks di atas--oleh para ahli sejarah dilihat sebagai ungkapan yang memiliki nuansa dan kecenderungan sufisme. Dalam tradisi sufisme, proses mimpi diakui sebagai bagian dari praktik-praktik keagamaan para sufi, sebagai sarana proses transmisi ilmu-ilmu keislaman. Bahkan al-Ghazālī berpendapat bahwa apa yang muncul dalam mimpi adalah sebuah perumpamaan (mïsia $l$ ); ia merupakan bentuk pengalaman spiritual yang dimiliki para sufi. Oleh karena itu, bisa dikatakan bahwa munculnya sufisme dalam wacana intelektual Islam di Nusantara berlangsung sejalan dengan proses Islamisasi.

TEOLOGIA, VOLUME 24, NOMOR 2, JULI-DESEMBER 2013 
SULAIMAN AL-KUMAYI: Gerakan Pembaruan...

Kenyataannya, Islam yang bercorak sufisme ini sedemikian dominan mewarnai wacana intelektual keagamaan yang terjadi, kendati dengan karakteristik, kecenderungan, dan penekanan yang relatif berbeda antarsatu periode dengan periode lainnya. Di antara sifat dan kecenderungan sufisme yang semakin menguat dari waktu ke waktu adalah munculnya apa yang disebut dengan neo-sufisme, yakni ajaran tasawuf yang menekankan adanya rekonsiliasi atau saling pendekatan antara ilmu tasawuf ('ilm al-haqìqah) dan ilmu syariah ('ilm al-syarīah).

\section{Tasawuf Model Kaum Pembaru: Neo-Sufisme}

Istilah neo-Sufisme (neo-Sufism) diperkenalkan oleh Fazlur Rahman. Tasawuf ini cikal bakalnya telah ada sejak masa salāf, namun dalam perkembangannya mengalami "kemandegan" dan baru dihidupkan kembali oleh ulama-ulama mazhab Hanbali, ${ }^{18}$ antara lain Ibn Taimiyyah. ${ }^{19}$ Menurut Masyharuddin, Ibn Taimiyyah sendiri dalam tulisan-tulisannya lebih suka menggunakan istilah alTașawwuf al-Masyrū' (tasawuf yang disyariatkan).Dengan kualifikasi al-Masyrü' mengindikasikan bahwa tasawuf yang dikehendakinya adalah tasawuf yang selalu berada dalam pangkuan syari'ah (agama). Yakni secara normatif dan metodologis memiliki rujukan yang jelas dari Qur'an dan Sunnah serta secara aplikatif memiliki contoh dan teladan dari praktik-praktik kerohanian Nabi dan generasi salaf. Dengan kualifikasi itu pula Ibn Taimiyyah menganggap bid'ah (baik bid'ah żātiyah/essensial maupun bid'ah manhajiyah/metodologis) terhadap tasawuf yang berada di luar bingkai syariat. ${ }^{20}$

Menurut Rahman, neo-Sufisme mempunyai ciri utama berupa tekanan kepada motif moral dan penerapan metode zikir dan murāqabah (konsentrasi kerohanian) guna mendekati Tuhan, tetapi sasaran dan isi konsentrasi itu disejajarkan dengan doktrin salafi (ortodoks) dan bertujuan untuk meneguhkan keimanan kepada akidah yang benar dan kemurnian moral dari jiwa. Melucuti dari ciri 
SULAIMAN AL-KUMAYI: Gerakan Pembaruan...

dan kandungan ekstatik dan metafisiknya, dan digantikan dengan kandungan yang sesuai dengan al-Quran dan Sunnah.21

Tasawuf model baru ini menekankan dan memperbarui faktor moral asli dan kontrol-diri yang puritan dalam tasawuf dengan mengorbankan ciri-ciri berlebihan dari tasawuf yang menyimpang (unorthodox sufism). Pusat perhatian neo-Sufisme adalah rekonstruksi sosio-moral dari masyarakat Muslim. Ini berbeda dengan tasawuf sebelumnya, yang terutama menekankan individu dan bukan masyarakat. ${ }^{22}$ Sehingga, karakter keseluruhan neo-Sufisme adalah puritan dan aktivis. ${ }^{23}$ Para pengamalnya tidak mengundurkan diri dari kehidupan dunia, tetapi sebaliknya melakukan inner detachment untuk mencapai realisasi spiritual yang lebih maksimal. ${ }^{24}$

Menurut Nurcholish Madjid, neo-Sufisme cenderung untuk menghidupkan kembali aktifisme salafi dan menanamkan kembali sikap positif kepada dunia. Dalam makna inilah kaum Hanbali seperti Ibn Taimiyah dan Ibn Qayyim al-Jauziyah, sekalipun sangat memusuhi sufisme populer, adalah jelas kaum neo-sufi, malah menjadi perintis ke arah kecenderungan ini. Selanjutnya, kaum neo-sufi juga mengakui, sampai batas tertentu, kebenaran klaim sufisme intelektual: mereka menerima kasyf (pengalaman penyingkapan kebenaran Ilahi) kaum sufi atau ilham intuitif tetapi menolak klaim mereka seolah-olah tidak dapat salah ( $m a$ șūm), dengan menekankan bahwa kehandalan kasyf adalah sebanding dengan kebersihan moral dari kalbu, yang sesungguhnya mempunyai tingkat-tingkat yang tak terhingga. ${ }^{25}$ Baik Ibn Taimiyah maupun Ibn Qayyim sesungguhnya mengaku pernah mengalami kasyf sendiri. Jadi terjadinya kasyf dibawa kepada tingkat proses intelektual yang sehat. Lebih jauh lagi, Ibn Taimiyah dan para pengikutnya menggunakan keseluruhan terminologi kesufian-termasuk istilah sālik, penempuh jalan keruhanian-dan mencoba memasukkan ke dalamnya makna moral yang puritan dan etos salafi. ${ }^{26}$

TEOLOGIA, VOLUME 24, NOMOR 2, JULI-DESEMBER 2013 
SULAIMAN AL-KUMAYI: Gerakan Pembaruan...

Berdasarkan kajian Nurcholish Madjid, neo-Sufisme itu dalam perkembangannya tampil dalam apa yang disebut oleh kelompok Dr. Sa'id Ramadhan "Al-Rūḥanìyat Al-Ijtimā"l̄yah" (spiritualisme sosial)27 yang ciri-cirinya: [1] membaca dan merenungkan makna kitab suci al-Quran; [2] membaca dan mempelajari makna kehadiran Nabi saw melalui sunnah dan sīrah (biografi) beliau; [3] memelihara hubungan dengan orang-orang saleh seperti para ulama dan tokoh Islam yang zuhud; [4] menjaga diri dari sikap dan tingkah laku tercela; [5] mempelajari hal-hal tentang ruh dan metafisika dalam Al-Quran dan Al-Sunnah, dengan sikap penuh percaya; [6] melakukan ibadatibadat wajib dan sunnah, seperti sembahyang lima waktu dan tahajjud. Setelah itu dikemukakan peringatan yang keras sekali terhadap palsunya hidup spiritualisme pasif dan isolatif (i'tizālīyah):

Di sini kita ingin memberi peringatan tentang sesuatu yang pelik dan penting, yaitu bahwa spiritualisme isolatif yang mengungkung pelakunya dari masyarakat sehingga ia tidak berhubungan dengan mereka dan mereka tidak berhubungan dengan dia, tidak pula dia memberi pelajaran kepada mereka dan dia tidak belajar dari mereka, ini adalah spiritualisme orang-orang yang lemah, yang tidak tahan menghadapi kejahatan dan bahaya, kemudian lari ke 'uzlah (pengucilan diri) dan berpegang kepada 'uzlah itu; dan spiritualisme dengan kaum egois yang hanya mencari kebahagiaan untuk diri mereka sendiri saja. Hal serupa itu, meskipun ada unsur kebaikan medium dan keluhuran tujuan di dalamnya, adalah jenis penyakit.28

Dengan demikian, yang paling dipentingkan di sini adalah nilai keseimbangan (mìzan atau tawāzun), sehingga prinsip utama hidup ideal seorang muslim diuraikan lebih lanjut.

Jika orang dengan lurus menghadapi dirinya sendiri kemudian memenuhi hak badannya dan hak ruhnya, maka ia telah berbuat adil kepada kemanusiaannya, sejalan dengan sunnatullah, dan hidupa dengan damai di dunia dan di akhirat.

Jika ia cenderung hanya kepada salah satu dari dua jurusan itu, sambil berpaling dari yang lain, maka ia telah berbuat zalim kepada 
SULAIMAN AL-KUMAYI: Gerakan Pembaruan...

dirinya, dan menghadapkan dirinya itu menentang sunnatullah. Barangsiapa menghadapkan dirinya menentang Kebenaran tentu hancur-"Engkau tidak akan mendapatkan perubahan dalam sunnatullah" (QS. Al-Ahzab [33]: 62). Maka orang yang hidup di zaman sekarang, yang hanya mementingkan harta, berlomba untuk sepotong roti, tenggelam dalam urusan badani, sibuk dengan kehormatan kosong dan kemegahan palsu, menyia-nyiakan tuntutan akal dan kalbunya hanya untuk kenikmatan muspra itu, dia adalah orang yang terkecoh dari hakikat dirinya, terdinding dari inti hidup. Ia menginginkan agar sunnatullah mengangkatnya ke alam yang lebih tinggi, namun tergelincir jatuh dari kemuliaan itu, dan tetap saja bertindak memutuskan tali hubungan tersebut. Sedangkan orang yang mengarahkan dirinya hanya untuk memenuhi tuntunan ruhnya menggunakan waktu siangnya untuk puasa dan malamnya untuk berdiri (salat), sepanjang umurnya untuk merenung semata sambil mengingkari hal-hal yang baik dari hidup duniawi lalu tidak berpakaian kecuali dengan yang kasar-kasar, tidak makan kecuali yang kering kerontang dengan tujuan agar potensi hidup lahiriahnya menjadi lemah dan-menurut anggapannya-agar potensi ruhaninya menjadi hebat, dia adalah juga orang yang bodoh tentang hakikat hidup, lalai akan sunnatullah, menyia-nyiakan hak badannya sendiri, atau menyia-nyiakan salah satu dari dua segi hidupnya. Cukup hal itu baginya sebagai kerugian dan pengingkaran terhadap perintah Allah. Diriwayatkan orang banyak bahwa Rasulullah saw mengunjungi 'Abdullah ibn 'Amr ibn Al-Aș, dan istrinya meminta belas kasihan Rasulullah saw., maka beliau bersabda, "Bagaimana keadaanmu, wahai ibu Abdullah?" Dijawabnya, "(dia itu, 'Abdullah ibn 'Amr ibn Al-'Aș) menyendiri, sehingga ia pun tidak tidur, tidak berbuka (puasa), tidak mau makan daging, dan tidak menunaikan kewajibannya kepada keluarganya." Beliau bertanya, "Di mana dia sekarang?" Dijawab, "Dia sedang keluar, dan sudah hampir pulang saat ini." Beliau bersabdda, "Kalau dia pulang, tahan dia untukku." Maka Rasulullah saw pun keluar, lalu Abdullah datang, dan Rasulullah

TEOLOGIA, VOLUME 24, NOMOR 2, JULI-DESEMBER 2013 
SULAIMAN AL-KUMAYI: Gerakan Pembaruan...

sudah hampir pulang. Maka beliau katakana, "Wahai Abdullah ibn 'Amr, bagaimana itu berita yang sampai kepadaku mengenai dirimu? Engkau tidak tidur!” Dijawabnya, "Dengan itu aku ingin aman dari marabahaya yang besar." Sabda beliau, "Dan sampai kepadaku (berita) bahwa engkau tidak berbuka (puasa)!" Dijawabnya, "Dengan itu aku menginginkan sesuatu yang lebih baik di surga." Beliau bersabda, "Dan sampai kepadaku (berita) bahwa engkau tidak menunaikan untuk keluargamu hak-hak mereka!" Dijawabnya, "Dengan itu aku menginginkan wanita yang lebih baik daripada mereka." Maka Rasulullah pun bersabda, "Wahai 'Abdullah ibn 'Amr, bagimu ada teladan yang baik pada Rasulullah. Dan Rasulullah itu berpuasa dan berbuka, makan daging, dan menunaikan untuk keluarganya hak-hak mereka. Wahai 'Abdullah ibn 'Amr, badanmu mempunyai hak atas engkau, dan sesungguhnya keluargamu mempunyai hak atas engkau!"

Dengan kebijakan yang mendalam itu Rasulullah saw menggambarkan untuk kita cara hidup yang sehat dan benar, dan menjelaskan bahwa sikap berlebihan adalah tercela, biarpun mengenai sikap seorang hamba dalam kehidupan ruhaninya. Sebab Allah tidak terima dari hamba-Nya jika sunnah-Nya diabaikan kemudian orang itu menyangka bahwa sikap tersebut membawanya kepada keridhaan-Nya. ${ }^{29}$

Di lain kesempatan peristiwa yang sama terjadi pada sahabat Nabi, 'Utsmān ibn Mazh'ūn. Diriwayatkan: istri 'Utsmān ibn Mazh'ūn bertandang ke rumah para istri Nabi saw dan mereka ini melihatnya dalam keadaan buruk. Maka mereka bertanya kepadanya: "Apa yang terjadi denganmu? Tidak ada di kalangan kaum Quraisy orang yang lebih kaya daripada suamimu!" Ia menjawab: “Kami tidak mendapat apa-apa dari dia. Sebab malam harinya ia beribadat, dan siang harinya ia berpuasa!" Mereka pun masuk kepada Nabi dan menceritakan hal tersebut. Maka Nabi pun menemui dia ('Utsmān ibn Mazh'ūn), dan bersabda: "Hai 'Utsmān! Tidakkah padaku ada teladan bagimu?" Dia menjawab: "Demi ayah ibuku, engkau memang 
SULAIMAN AL-KUMAYI: Gerakan Pembaruan...

demikian." Lalu Nabi bersabda: "Apakah benar engkau berpuasa setiap hari dan tidak tidur (beribadat) setiap malam?" Dia menjawab: "Aku memang melakukannya." Nabi bersabda: "Jangan kau lakukan! Sesungguhnya matamu punya hak atas engkau, dan keluargamu punya hak atas engkau! Maka sembahyanglah dan tidurlah, puasalah dan makanlah!"

'Utsmān ibn Mazh'ūn membeli sebuah rumah, lalu ia tinggal di dalamnya (sepanjang waktu) untuk beribadat. Berita itu datang kepada Nabi saw, maka beliaupun datang kepadanya, lalu dibawanya ke pintu keluar rumah di mana ia tinggal, dan beliau bersabda: "Wahai 'Utsmān, sesungguhnya Allah tidaklah mengutus aku dengan ajaran-ajaran kerahiban." (Nabi bersabda demikian dua tiga kali, lalu bersabda lebih lanjut), "Dan sesunggunya sebaik-baik agama di sisi Allah ialah al-hanifiyat al-samhah (semangat pencarian Kebenaran yang lapang)."30

\section{Neo-Sufisme Gelombang Pertama}

Azra ${ }^{31}$ menegaskan bahwa sepanjang menyangkut perkembangan Islam, khususnya di abad XVII M, neo-sufisme merupakan wacana dominan dalam jaringan ulama Nusantara dengan Timur Tengah. Sejak awal abad XVII, Timur Tengah, khususnya Makkah dan Madinah, menyaksikan berkembangnya pemikiran Islam aliran neosufisme. Sehingga, sebagai wilayah yang terlibat dalam proses transmisi keilmuan Islam dari Timur Tengah tersebut, Nusantara juga memperlihatkan kecenderungan Islamnya yang neo-sufis tersebut.

Abad XVII M dalam sejarah Islam di Nusantara memang merupakan periode penting yang mencatat perkembangan sangat berarti dalam pembentukan tradisi intelektual Islam. Perkembangan ini terjadi sejalan dengan terjalinnya hubungan yang semakin intensif antara dunia Melayu-Nusantara dengan Timur Tengah, yakni Makkah dan Madinah. Kedua kota suci tersebut saat itu tengah berkembang menjadi pusat berlangsungnya studi-studi Islam oleh

TEOLOGIA, VOLUME 24, NOMOR 2, JULI-DESEMBER 2013 
SULAIMAN AL-KUMAYI: Gerakan Pembaruan...

para ulama di dunia Muslim, termasuk Melayu-Nusantara. Melalui para ulama inilah transmisi keilmuan Islam di Melayu-Nusantara berkembang semakin kuat. Para ulama ini selanjutnya membentuk satu "jaringan ulama" Melayu-Nusantara dengan Timur Tengah yang berfungsi sebagai sarana berlangsungnya proses transmisi keilmuan Islam ke Melayu Nusantara. Sebagian besar ulama terkemuka di Nusantara pernah belajar di Timur Tengah, khususnya Makkah dan Madinah.

Penting dijelaskan, pada abad XVII hubungan Melayu-Nusantara dengan Timur Tengah memang terjalin sangat intensif. Perkembangan politik dan ekonomi kerajaan-kerajaan Islam di Nusantara, khususnya kerajaan Aceh, telah menempatkan dunia MelayuNusantara memiliki akses langsung dalam berhubungan dengan dunia Timur Tengah. Bukti-bukti sejarah menunjukan bahwa bahwa pada abad XVII terjadi peningkatan hubungan yang semakin intensif dari dua dunia Muslim tersebut. Hal ini terjadi selain melalui ibadah haji-yangmengalami peningkatan sejalan perkembangan perdagangan di Lautan Hindia--tapi yang terpenting adalah hubungan para ulama yang terjalin melalui sebuah jaringan yang sangat kompleks. Meski tidak sedikit yang awalnya hanya bertujuan melaksanakan ibadah haji, para ulama kemudian belajar Islam di Makkah dan Madinah dalam waktu yang sangat lama. Para ulama inilah kemudian menjadi tokoh intelektual terkemuka yang bertanggung jawab atas penyebaran dan sosialisasi pemikiran-pemikiran Islam yang mereka pelajari selama berada di Timur Tengah.

Salah seorang ulama yang bertanggungjawab memperkenalkan pemikiran neo-sufisme kepada para ulama Nusantara adalah Ibrāhīm al-Kuranī (1614-1690), seorang ulama terkemuka di Haramayn asal Kurdi. Ia menjadi guru bagi kebanyakan ulama Nusantara yang belajar dan bermukim di Makkah dan Madinah. Di antara ulama Nusantara yang pernah berguru kepadanya adalah alSinkili al-Sinkili dan Muhammad Yusuf al-Makassari. Al-Kuranī diketahui mendapatkan pendidikan awal di tempat kelahirannya, 
SULAIMAN AL-KUMAYI: Gerakan Pembaruan...

sebelum kemudian ia belajar di Iran dan di wilayah-wilayah Usmania Anatolia, Syria dan Mesir. Hal terpenting untuk ditekankan dalam konteks neo-sufisme ini adalah bahwa Ibrāhīm al-Kuranī dikenal sebagai seorang yang memberi perhatian pada upaya mendamaikan aliran-aliran dalam pemikiran Islam yang kerap kali bertentangan satu sama lain, khususnya antara para ulama sufi dan ulama fikih.

Sebagaimana telah diisyaratkan di atas, aspek paling menonjol dari pemikiran neo-sufisme adalah adanya saling pendekatan (raproachment) antara para ulama yang lebih berorientasi syariah (ahl al-syari’ah), khususnya mereka yang kerap disebut para ahli fikih, dan para ulama yang lebih menekankan praktik-praktik sufisme (ahl al-haqīqah). Oleh karena itu, dalam se jarah pemikiran Islam, neo-sufisme ini sedikit banyak diakui merupakan pembaharuan yang berusaha menjadikan sufisme sejalan dengan syariah. Hal ini lahir karena kon $\neg$ flik yang tajam antara dua kelompok pemikir Islam di atas. Bahkan, konflik ini telah merenggut korban dengan meninggalnya para sufi, seperti yang dialami al-Hallāj, karena tuduhan tidak menjalankan hukum-hukum atau ketentuanketentuan yang ditetapkan syariah. Demikianlah, sejak sekitar abad XII, khususnya diwakili Abū Muhammad al-Ghazālī (w. 1111), rekonsiliasi sufisme dan syariah merupakan wacana dominan dalam perkembangan pemikiran Islam. Al-Ghazālī berpendangan bahwa sufisme yang dijalankan para sufi eskatik seperti Ibn 'Arabī, harus diletakkan kembali dalam kerangka syariah.

Dalam konteks Melayu-Nusantara, khususnya di Kerajaan Aceh-seperti akan dijelaskan secara rinci kemudian--gagasan-gagasan neo-sufisme diketengahkan para ulama $\mathrm{Nu}\urcorner$ santara yang belajar di Timur Tengah, yaitu Nuruddin ar-Raniri (w. 1658), al-Sinkili alSinkili (1615-1693), dan Yusuf al-Makassari (1627-1699) pada abad XVII; serta Muhammad al-Palimbani dan Abu Daud al-Patani pada abad XVIII. Mereka, lebih-lebih al-Raniri, mewakili gerakan Islam neo-sufisme di Melayu-Nusantara yang menentang aliran sufisme wahdah al-wujūd yang ditanamkan pengikut Ibn 'Arabī, khususnya Hamzah al-Fansuri dan Syamsuddin al-Sumatrani (w. 1630).

TEOLOGIA, VOLUME 24, NOMOR 2, JULI-DESEMBER 2013 
SULAIMAN AL-KUMAYI: Gerakan Pembaruan...

\section{Neo-Sufisme Gelombang Kedua: HamkaSebuah Kasus}

Untuk kasus neo-sufisme di Indonesia, maka sosok Hamka adalah sangat representatif. Ia telah menulis buku-buku tentang tasawuf dan kritikannya sekaligus, dan ia sekaligus pelaku yang mempraktikkan hidup kesufian. ${ }^{32}$

Nurcholish Madjid dalam sebuah wawancaranya pernah menyinggung sosok Hamka sebagai "di satu pihak begitu modernis dan reformis, tapi di pihak lain dia juga menerima dan mengembangkan sufi."33 Posisi ini memang penuh risiko jika kita lihat dari background ke-Muhammadiyah-an Hamka. Mengingat, kehadiran gerakan Muhammadiyah antara lain dimaksudkan untuk memurnikan Islam di Indonesia dari praktik-praktik khurafat tradisional yang tidak Islami.34 Tetapi, seperti diakui budayawan dan sastrawan Kuntowijoyo, dalam Muhammadiyah tetap ada unsur sufisme. ${ }^{35}$

Kehadiran Hamka dengan Tasauf Moderen-nya, menandai babak baru dasar-dasar sufisme baru di Indonesia. Menurut Nurcholish Madjid, merujuk buku Tasauf Modern, memberi petunjuk kepada kita tentang adanya apresiasi Hamka yang wajar kepada penghayatan esoteris Islam. Di samping itu, memberikan peringatan bahwa esoterisme itu harus tetap terkendalikan oleh ajaran-ajaran standar syari'ah. Jadi, sesungguhnya Hamka masih tetap dalam garis kontinuitas dengan pemikiran Imam al-Ghazālī. Bedanya dengan alGhazālī ialah bahwa Hamka menghendaki suatu penghayatan keagamaan esoteris yang mendalam tetapi tidak dengan melakukan pengasingan diri atau 'uzlah, melainkan tetap aktif melibatkan diri dalam masyarakat. ${ }^{36}$

Menurut Damami, istilah tasawuf modern merupakan lawan terhadap tasawuf tradisional. Tasawuf yang ditawarkan Hamka berdasar pada prinsip tauhid, bukan pencarian pengalaman mukasyafah; jalan tasawufnya lewat sikap zuhud yang dapat dilaksanakan dalam peribadatan resmi. Sikap zuhud tidak perlu terus-menerus bersepi-sepi diri dengan menjauhi kehidupan 
SULAIMAN AL-KUMAYI: Gerakan Pembaruan...

normal; penghayatan tasawufnya berupa pengalaman takwa yang dinamis, bukan ingin "bersatu dengan Tuhan"(unitive state); dan refleksi tasawufnya berupa menampakkan makin meningginya kepekaan sosial dalam diri si sufi (disebut juga "karamah dalam arti sosio-religius") bukan karena ingin mendapat "karamah" yang bersifat magis, metafisis dan sebangsanya. ${ }^{37}$

Mencermati pemikiran Hamka di bidang tasawuf ini, konsep dasar yang ia tawarkan adalah sufisme yang berorientasi "ke depan" yang ditandai dengan mekanisme dari sebuah sistem ketasawufan yang unsur-unsurnya meliputi prinsip tauhid, dalam arti menjaga transendensi Tuhan dan sekaligus merasa "dekat dengan Tuhan.". Dan memanfaatkan peribadatan sebagai media bertasawuf, dalam arti di samping melaksanakan perintah agama juga mencari hikmah yang berupa sikap positif terhadap hidup dalam wujud memiliki etos sosial yang tinggi.38 Lebih jauh Hamka mengatakan:

Tasawuf ialah hubungan diri dengan Tuhan dan hubungan diri dengan masyarakat. Bilamana telah diperkuat diri karena hubungan dengan Tuhan, maka diri itupun kena sinar daripada Tuhan, kilau kemilau cahayanya dan tinggi mutunya. Diri yang mendapat limpahan Nur Ilahi itulah yang dibawa ke tengah masyarakat...Sebab yang hendak dikurbankan itu hendaklah barang yang bermutu. Pribadi yang bermutu menimbulkan masyarakat yang bermutu. Batas di antara seorang penyembah benda yang egoistis (mementingkan diri sendiri) dengan seorang Shufi yang lari dari masyarakat sangatlah tipis. Seorang ahli tasawuf yang senantiasa duduk dalam tempatnya bersuluk menghitung tasbih memohonkan pahala atau hendak mensucikan diri sendiri dan tidak mempedulikan masyarakat adalah juga seorang yang egoistis, mementingkan dirinya sendiri. ${ }^{39}$

Ditambahkan oleh Hamka, semangat Islam ialah semangat berjuang, semangat berkurban, bekerja, bukan semangat malas, lemah, rapuh, dan mlempem. ${ }^{40}$

Hamka mengakui bahwa bekas pendidikan tasawuf yang melemahkan itu sangat besar di Indonesia dan dunia Islam seluruhnya.

TEOLOGIA, VOLUME 24, NOMOR 2, JULI-DESEMBER 2013 
SULAIMAN AL-KUMAYI: Gerakan Pembaruan...

Ini menimbulkan akibat yang cukup membekas pada masyarakat kaum Muslim, katanya:

Sekian lamanya kaum Muslimin membenci dunia dan tidak menggunakan kesempatan sebagaimana orang lain. Lantaran itu mereka menjadi lemah. Akan berkorban, tidak ada yang akan dikorbankan, karena harta benda dunia telah dibenci. Akan berzakat, tidak ada yang akan dizakatkan, karena mencari harta dikutuki. Orang lain maju di lapangan penghidupan, mereka mundur. Dan apabila ada yang berusaha mencari harta benda, mereka dikatakan telah jadi orang dunia. ${ }^{41}$

Fenomena ini disinyalir oleh Hamka sebagai tasawuf yang telah menyimpang dari ajaran Islam. Ia mengutip kata-kata tokoh Muhammadiyah KH. Mas Mansur yang pernah mengatakan: "80\% didikan Islam kepada keakhiratan dan 20\% kepada ke uniaan. Tetapi kita telah lupa mementingkan yang tinggal 20\% lagi itu, sehingga kita menjadi hina." Melihat situasi yang menghinggapi umat Islam itu, Hamka, dalam melurusukan tasawuf merasa perlu menegaskan hakikat Islam, katanya:

Agama Islam adalah agama yang menyeru umatnya mencari rezeki dan mengambil sebab-sebab buat mencapai kemuliaan, ketinggian dan keagungan dalam perjuangan hidup bangsabangsa. Bahkan agama Islam menyerukan menjadi yang dipertuan di dalam alam dengan dasar keadilan, memungut kebaikan di mana pun juga bersuanya, dan membolehkan peluang mencari kesenangan yang diizinkan. ${ }^{42}$

Berdasarkan pengamatannya terhadap pemikiran sufistik Hamka, Dawam Rahardjo sampai pada kesimpulan bahwa maksud Hamka menulis tasawuf modernnya adalah meletakkan tasawuf kepada relnya, dengan menegakkan kembali maksud semula tasawuf, yakni guna "membersihkan jiwa, mendidik, dan memperhalus perasaan, menghidupkan hati dalam menyembah Tuhan dan mempertinggi derajat budi pekerti."43

Menurut Abdurrahman Wahid, salah satu sumbangan terbesar Hamka-di luar Tafsir Al-Azhar-adalah "berhasil mendudukkan kembali beberapa aspek ilmiah yang tadinya hilang dari perhatian 
SULAIMAN AL-KUMAYI: Gerakan Pembaruan...

sebagian kelompok Muslim dalam pengetahuan tentang agama mereka, yaitu tentang tasawuf." 44 Sebagai obyek kajian ilmiah, tasawuf pernah menjadi momok bagi kalangan pembaruan diperempat pertama abad XX, sebagian besar karena penolakan mereka atas praktek-praktek kaum tarekat penganut tasawuf, yang salah dan bahkan bertentangan dengan ajaran agama dalam pandangan mereka. Di sinilah, tegas Abdurrahman Wahid, kehadiran Buya Hamka lewat Tasawuf Modern-nya memberi legitimasi kepada kecenderungan yang memang sebenarnya sudah ada, tetapi masih tersembunyi oleh semangat "memperbarui" yang mewarnai sikap para pengikut gerakan Muhammadiyah pada masa-masa permulaan pertumbuhannya. ${ }^{45}$

Menurut Nurcholish Madjid, Buya Hamka banyak sekali dipengaruhi oleh al-Ghazālī, terutama IhyyāUlūm al-Dīn. ${ }^{46}$ Dalam sebuah wawancaranya dengan M. Nasruddin Anshory Ch, dari majalah Horison edisi No. 4, 23 April 1989, Nurcholish Madjid berkomentar tentang Hamka:

Meskipun sebagai orang Muhammadiyah, beliau itu banyak mengambil prinsip-prinsip dasar dari keyakinan keagamaannya orang seperti Ibn Taymīyah, tetapi dia, seperti tercermin dalam buku-bukunya itu, sangat banyak dipengaruhi oleh alGhazālī. Dan memang Buya Hamka adalah orang yang punya akses, karena ada kemampuan untuk membaca. Sehingga wajar kalau dia menjadi kaya dalam pemikiran sufi ini. Saya kira tidak banyak orang seperti Buya Hamka itu, di mana di satu pihak begitu modernis dan reformis, tapi di pihak lain dia juga menerima dan mengembangkan sufi. Maka dia juga menulis buku Tasawuf Modern. Dalam Tasawuf Modern itu, Buya Hamka bermaksud menonjolkan segi-segi kesufian dari ibadah Islam, tanpa menjadi pengikut gerakan tarekat. Jadi bertasawuf dalam artinya yang murni. ${ }^{47}$

Memang, sebagai seorang reformis dan modernis, Hamka melancarkan kritik-kritik yang pedas terhadap tasawuf dan kaum sufi. Tetapi, sebagaimana diamati oleh Nurcholis Madjid, yang menjadi sasaran kecaman Hamka sebenarnya bukanlah tasawuf itu an sich, melainkan tasawuf sebagaimana diamalkan orang banyak. ${ }^{48}$

TEOLOGIA, VOLUME 24, NOMOR 2, JULI-DESEMBER 2013 
SULAIMAN AL-KUMAYI: Gerakan Pembaruan...

Di sini-meminjam kategorisasi Nurcholis Madjid-Hamka sesungguhnya menggunakan kategori analitis "sufisme-filosofis" dan "sufísme-populer".49 Dalam tataran "sufisme-filosofis", Hamka mendukung tasawuf, bahkan dia ikut mengembangkan dan meluruskannya dengan berbagai karangan, baik dalam bentuk buku, seperti Tasawuf Modern, maupun dalam bentuk karya-karya yang lebih pendek. ${ }^{50}$

Dalam tataran "sufisme-populer", Hamka dengan gencar mengkritik praktik-praktik sufisme yang diilihatnya menyimpang dari ajaran Islam yang sesungguhnya. Praktik-praktik bid'ah seperti dalam kebiasaan mengkultuskan guru, pemimpin, wali, dan lainlainnya. Kebiasaan mengkultuskan seorang tokoh ini tidak saja dilakukan ketika sang tokoh masih hidup, bahkan setelah dia meninggal sikap mengkultuskannya ini semakin mengental. Mitologi terhadap tokoh-tokoh ini melahirkan kebiasaan memuja kuburan, seperti dikatakan Hamka:

Sudah beratus tahun faham tasawuf yang telah jauh terbelok dari pangkalnya itu mempengaruhi masyarakat Muslim. Berpuluh-puluh makam dibangun orang, kemudian makammakam ini dikeramatkan. Dan ini banyak kita jumpai di setiap negeri Islam...Pendeknya, suasana pada waktu itu adalah suasana kuburan. ${ }^{51}$

"Suasana kuburan" yang disaksikan Hamka sudah menjurus pada apa yang dia gambarkan: "Bukan lagi mendoakan, kiranya orang berkubur itu dilapangi Allah, tetapi memohonkan apa-apa kepada yang berkubur itu. Atau bernazar, jika kiranya suatu kehendaknya tercapai, karena pemujaannya kepada kubur itu dia berjanji akan datang lagi ke sana, mengucapkan terima kasih dan menyampaikan apa-apa sedekah yang akan diterima dengan senang hati oleh juru kunci!"52 Padahal, tegas Hamka, Tuhan berkali-kali mengatakan dengan perantaraan rasul-Nya, bahwa Dia dekat kepada hamba-Nya daripada urat leher hamba itu sendiri. ${ }^{53}$ Bahkan, seorang penyair sufi pun pernah berkata: "Janganlah engkau meminta apaapa kepada sesamamu Anak Adam. Tetapi mohonkanlah terus kepada yang pintu-Nya tidak pernah tertutup. Allah murka kalau engkau 
SULAIMAN AL-KUMAYI: Gerakan Pembaruan...

tinggalkan memohon kepada-Nya. Dan Anak Adam marah kalau engkau selalu meminta kepadanya." 54

\section{Paham Kesufian Hamka}

Berdasarkan kajian-kajiannya terhadap karya-karya Hamka, Nurcholish Madjid sampai pada kesimpulan bahwa inti dari faham kesufian Hamka adalah sebagai berikut:Pertama, tauhïd, dalam arti faham ketuhanan yang semurni-murninya, yang tidak mengizinkan adanya mitologi terhadap alam dan sesama manusia. Termasuk juga faham kultus (culturism) yang dipraktikkan oleh banyak kaum Muslimin.

Kedua, tanggung jawab pribadi dalam memahami agama. Artinya, tidak boleh "pasrah" kepada otoritas orang lain-betapa pun tinggi ilmunya-dalam bentuk taklid buta. Dengan tandas beliau membela faham tentang terbukanya pintu ijtihad.

Ketiga, taqarrub, dengan menghayati sebaik-baiknya makna ibadat yang telah ditetapkan oleh agama, dan melalui ibadat itu mendekatkan diri sedekat-dekatnya kepada Allah Swt.

Keempat, akhlāq al-karīmah atau budi pekerti luhur. Simbol dan ekspresi lahiriah keagamaan memang penting, namun manusia diharuskan harus bisa menangkap makna di balik itu semua. Makna ini terutama berupa pendidian moralitas, etika, dan akhlak yang mulia.

Terakhir, sebagai kelanjutan dari akhlāq al-karimah ini kita diharuskan aktif melibatan diri dalam kehidupan sosial. Beragama dengan serius tidak berarti harus meninggalkan kehidupan duniawi, tetapi malah harus mendorong untuk ambil bagian dalam usaha bersama memperbaiki masyarakat. Sehubungan dengan masalah ini beliau mengatakan, "Mengisi pribadi dengan sifat-sifat yang ada pada Tuhan, yakni sifat-Nya, yang dapat kita jadikan sifat kita, menurut kesanggupan yang ada pada kita...Bertasawuf tetapi bukan menolak hidup. Bertasawuf, lalu meleburkan diri ke dalam gelanggang masyarakat."55

TEOLOGIA, VOLUME 24, NOMOR 2, JULI-DESEMBER 2013 
SULAIMAN AL-KUMAYI: Gerakan Pembaruan...

\section{Tanpa Tarekat}

Sekalipun Hamka sangat apresiatif, bahkan pengamal tasawuf, ia tidak pernah berafiliasi ke aliran tarekat mana pun di dunia ini. Ia juga tidak pernah membuat aliran tarekat tersendiri, sebagaimana lazimnya dalam dunia tarekat.

Berbeda dengan tokoh reformis-modernis lainnya, Hamka tetap menaruh hormat kepada mereka yang bergabung dan mengamalkan tarekat tertentu. Sikap respeknya ini dapat kita ketahui dari pembahasannya mengenai pengaruh tasawuf dalam dakwah Islam. Menurutnya tasawuf telah berjasa besar dalam penyebaran agama Islam. Selain berhasil memperkuat jiwa kaum Muslimin dalam mempertahankan agama Islam, tasawuf juga telah berhasil memompa jiwa kaum Muslimin dalam menghadapi penjajahan bangsa asing.

Ia mengambil kasus Tarekat Sanusiyah, yang didirikan oleh Sayid Muhammad bin Ali Al-Sanusi, di Afrika. Tarekat ini telah berjasa dalam mempertahankan agama Islam dan menjadi pemompa jiwa kaum Muslimin di Libya dalam mengusir penjajahan Italia. ${ }^{56}$

\section{Penutup}

Dari uraian di atas dapat diambil kesimpulan bahwa gerakan pembaruan tasawuf di Indonesia terfokus pada mengembalikan tasawuf ke "pangkalnya" sehingga sesuai dengan tuntunan al-Quran dan al-Sunnah. Pembaruan tasawuf gelombangan pertama dan kedua di Nusantara, ternyata sama-sama fokus pada pengembalian tasawuf tersebut. Namun yang cukup menarik adalah fakta bahwa para pembaru tasawuf tersebut tidak serta merta mengharamkan tasawuf sebagaimana yang dilakukan oleh gerakan salafi, tetapi lebih pada menjaga agar tasawuf tidak melenceng dari jalurnya. []

\section{Catatan Akhir}

${ }^{1}$ Sebagai gambaran tentang masa kegelapan dan kemunduran dunia Islam; lihat: Harun Nasution, Pembaharuan Dalam Islam: Sejarah Pemikiran dan Gerakan, Jakarta: Bulan Bintang, 1992, h. 11-27. 
${ }^{2}$ Marshal G. Hodgson, The Venture of Islam, Vol. III, Chicago: Chicago Univesiry Press, 1974, h. 134.

${ }^{3}$ Lihat: Elizabeth Sirriyeh, Sufis and Anti-Sufis: The Defense, Rethinking and Rejection of Sufism in the Modern World, Richmond, Surrey: Curzon Press, 1999.

${ }^{4}$ Ibid., h. 1.

5 Ibid.

${ }^{6}$ A. J. Arberry, Sufism: An Account of the Mystics of Islam, London: George Allen and Unwin Ltd, 1950, h. 121. 68.

${ }^{7}$ Hamka, Pelajaran Agama Islam, Jakarta: Bulan Bintang, 1992, h. 67-

${ }^{8}$ A. J. Arberry, Sufism, h. 121.

${ }^{9}$ Harun Nasution, Pembaharuan, h. 23-24.

${ }^{10}$ Elizabeth Sirriyeh, Sufi and Anti-Sufis, h. 3.

11Dikutip dari Elizabeth Sirriyeh, Sufis and Anti-Sufis, h. 4.

12Ibid.

${ }^{13}$ Ibid.

${ }^{14} \mathrm{Abu}$ Bakar Aceh, Pengantar Sejarah Sufi dan Tasawwuf, Solo: Ramadhani, 1993, h. 369.

${ }^{15}$ Azyumardi Azra, Renaisans Islam Asia Tenggara: Sejarah Wacana \& Kekuasaan, Bandung: Remaja Rosdakarya, 1999, h. 35.

${ }^{16} \mathrm{~A}$. H.Johns, "Sufism as a Category in Indonesia Literature and History", JSEAH, 2, II,1961.

17Lihat Oman Fathurahman dan Jajat Burhanuddin, "Tradisi dan Wacana Intelektual Islam Indonesia", artikel diakses darihttp:// naskahkuno.blogspot.com/2007/07/neo-sufisme-ghazalian-abdussamadal.html 11-02-2009.

18Juga disebut Ḥanābilah yang dirintis oleh Ahmad ibn Muḥammad ibn Hanbal w. $855 \mathrm{M}$ atau biasa disebut Imam Hanbal. Dia adalah murid Abū Yusūf dan Imām Syāfi ī w. 795 M. corak pemikirannya tradisionalisfundamentalis. Pandangan-pandangannya didasarkan pada Qur'an, Sunnah dan pendapat sahabat. Tapi jika terpaksa ia juga menggunakan hadis Mursal dan qiyas. Mazhab Hanbali banyak berkembang di Irak, Mesir, Syria, Palestina dan Saudi Arabia lih. Dewan Redaksi Ensiklopedi Islam, Ensiklopedi Islam, Vol. IV [Jakarta: PT. Ichtiar Baru van Hoeve, 2002], h. 216.

${ }^{19}$ Kehadiran Ibn Taimiyyah sebagai tokoh sufi sedikit ada perbedaan di kalangan para pengkajinya. Pandangan yang menyatakan bahwa ia adalah tokoh sufi dapat dibaca dalam beberapa tulisan berikut: Al-Tablawī Maḥmūd Sa`ād, al-Tașawwuf fi Turāś Ibn Taimiyah, Kairo: T.p., 1984, h. 18;

TEOLOGIA, VOLUME 24, NOMOR 2, JULI-DESEMBER 2013 
lihat juga Abdul-Fattah Sayyid Ahmad, Tasawuf antara Al-Ghazali dan Ibnu Taimiyah, penerj. Muhammad Muchson Anasy, Jakarta: Khalifa, 2005; George Makdisi, "Ibn Taimiya: a Sufi of the Qādiriya Order", American Journal of Arabi Studies,AJAS 1 1974, h. 118-129, juga ada dalam Religion, Law and Learning in Classical Islam Hampshire and Vermont: Variorum, 1991; Masyharuddin, Pemberontakan Tasawuf: Kritik Ibn Taimiyah atas Rancang Bangun Tasawuf, Surabaya: JP Books-STAIN Press Kudus, 2007. Adapun pendapat yang menyatakan bahwa Ibn Taimiyyah bukanlah sufi adalah Fritz Meier, "Des sauberste uber die vorbesstimmung. Ein Stuck Ibn Taymiyyah”, Saeculum 32 1981, h. 74-89.

${ }^{20}$ Masyharuddin, Pemberontakan Tasawuf: Kritik Ibn Taimiyah atas Rancang Bangun Tasawuf,Surabaya: JP Books-STAIN Press Kudus, 2007, h. 12.

21Fazlur Rahman, Islam, edisi II, Chicago: University of Chicago Press, 1979, 205-206.

22Fazlur Rahman, "Revival and Reform", dalam P. M. Holt et.al, The Cambridge History of Islam, 1970, II, h. 637.

23Fazlur Rahman, Islam, h. 194.

${ }^{24}$ Azyumardi Azra, Historiografi Islam Kontemporer: Wacana, Aktualitas dan Aktor Sejarah,Jakarta: Gramedia, 2002, h. 194.

${ }^{25}$ Nurcholish Madjid, Islam Agama Peradaban: Membangun Makna dan Relevansi Doktrin Islam Dalam Sejarah,Jakarta: Paramadina, 1995, h. 94.

Islam Agama Peradaban, h. 93-94.

26Ibid., h. 94.

${ }^{27}$ Gerakan neo-sufisme ini berpusat di Jenewa Swis yang diketuai Dr. Sa id Ramadhan dengan buku pegangan utamanya Al-Rūhanìyat AlIjtimā' 'ìah fi Al-Islām 1965. Dalam buku ini diuraikan secara komprehensif tasawuf model baru yang sesuai dengan Al-Quran dan Sunnah.

28Ibid., h. 95;

29Ibid., h. 96-97.

${ }^{30}$ Lihat: Jamāl al-Dīn Abūal-Faraj `Abd al-Raḥmān ibn JawzīalBaghdādī, Talbīs Iblīs,Kairo: Idārat al-Ṭibā’at al-Munīrīyah, 1368 H, h. 219220.

${ }^{31}$ Azyumardi Azra, Jaringan Ulama Timur Tengah dan Kepulauana Nusantara Abad XVII dan XVIII: Melacak Akar-akar Pembaruan Pemikiran Islam di Indonesia, Bandung: Mizan, 1994.

32Lihat: Amin Syukur, Zuhud di Abad Modern, Yogyakarta: Pustaka Pelajar, 1997, h. 128-133.

${ }^{33}$ Nurcholish Madjid, Dialog Keterbukaan, h. 320. 
SULAIMAN AL-KUMAYI: Gerakan Pembaruan...

${ }^{34}$ Alwi Shihab, Membendung Arus: Respons Gerakan Muhammadiyah Terhadap Penetrasi Misi Kristen di Indonesia,Bandung: Mizan, 1998, h 105.

35Lihat: Pengantar Kuntowijoyo untuk buku Alwi Shihab, Membendung Arus, h. XX

36Nurcholish Madjid, Islam Agama Peradaban: Membangun Makna dan Relevansi Doktrin Islam Dalam Sejarah,Jakarta: Paramadina, 1995, h 92.

37Mohammad Damami, Tasawuf Positif, h. 243.

38Ibid., h. 243-244.

${ }^{39}$ Hamka, Said Jamaluddin Al-Afghany, h. 59.

${ }^{40}$ M. Dawam Rahardjo, Intelektual, Intelegensia dan Perilaku Politik Bangsa: Risalah Cendekiawan Muslim, Bandung: Mizan, 1993, h. 204.

41 Ibid., h. 205.

42Ibid.

43Ibid.

${ }^{44}$ Abdurrahman Wahid, "Benarkah Buya Hamka seorang Besar?", h. 30.

45Ibid., h. 31.

${ }^{46}$ Dalam kata sambutannya untuk terjemahan Ihyō 'Ulūm al-Dīn oleh Ismail Yakub, Hamka mengakui, "Di zaman modern ini, saya sendiri amat banyak mengambil buah renungan Ghazālī untuk buku saya Tasauf Moderen."Lih.Ihya' Al-Ghazali, Jil.I, penerj. Prof. Tk. H. Ismail Yakub, SH, MA, Jakarta: CV. Faizan, 1994, h. 17.

${ }^{47}$ Wawancara ini telah dibuat dalam Nurcholish Madjid, Dialog Keterbukaan: Artikulasi Nilai Islam dalam Wacana Sosial Politik Kontemporer,Jakarta: Paramadina, 1998, h. 319-320.

48Menurut Dawam Rahardjo, sasaran utama kritik Hamka terhadap tasawuf disebabkan oleh munculnya ajaran-ajaran kebatinan, terutama kebatinan Jawa, selain adat istiadat dan nilai-nilai budaya setempat di daerah-daerah lain yang sering masih tercampur dengan kepercayaankepercayaan animisme dan dinamisme. Islam, seperti dikatakan oleh berbagai ahli sejarah seperti Prof. Dr. Priyono, masuk ke Indonesia melalui India dengan membawa unsur-unsur tasawuf.Dengan pendekatan tasawuf ini, Islam menjadi lebih mudah diterima, dengan konsekuensi, Islam membiarkan dirinya tercampur dengan tradisi dan nilai-nilai budaya lokal. Muhammadiyah_di mana Hamka adalah salah seorang pengikut, penyebar dan salah seorang pengurus Pimpinan Pusat Muhammadiyah-datang untuk membersihkan unsur-unsur tersebut, dengan keyakinan bahwa Islam demikian itu akan bisa membawa umat ke arah kemajuan. Memperkenalkan tasawuf bisa berarti melawan arus reformasi yang

TEOLOGIA, VOLUME 24, NOMOR 2, JULI-DESEMBER 2013 
SULAIMAN AL-KUMAYI: Gerakan Pembaruan...

dibawa oleh Muhammadiyah M. Dawam Rahardjo, Intelektual, Intelegensia, h. 204.

${ }^{49}$ Nurcholis Madjid, Tradisi Islam, h. 126.

${ }^{50}$ Barangkali agak mengejutkan bagi sementara orang kalau Hamka mengatakan bahwa Jamāl al-Dīn al-Afghānī sebagai penganut tasawuf. Menurut Hamka, tokoh pembaharu Islam tersebut adalah seorang peminat tasawuf. "Jamāl al-Dīn seorang peminat tasawuf.Muridnya Mohammad Abduh pun seorang yang menyukai hidup bertasawuf.Tasawuf bagi mereka adalah akibat yang wajar dari perasaan tauhid. Tetapi Jamāl al-Dīn tidak membutakan matanya daripada kerusakan yang telah menimpa Islam karena dalam tasawuf itu menyelinap pula ajaran yang lain yang bukan dari Islam asalnyał، Jamāl al-Dīn tidak lepaskan tasbih dari tangannya walaupun sedang duduk menghadapi majlis raja-raja. Pada suatu hari dibilangbilangnya juga tasbihnya itu di hadapan Sultan Abdul Hamid. Lalu datang bintara istana memberi peringatan bahwa membilang-bilang tasbih di hadapan majlis raja adalah satu perbuatan yang kurang sopan. Dengan murka beliau menjawab, 'Kau tahu hai bintara! Sultan mengambil tengkorak rakyatnya dijadikan tasbih dan digoyangkannya menurut sekehendak hatinya, tak ada orang yang berani melarang. Padahal tasbih itu kepunyaan saya sendiri, tidak mengganggu orang lain, dan tidak saya hitung dengan menggoyangkannya, ini tidak lain hanyalah nama Tuhanku!' Itulah satu contoh yang simbolik dari tasawufnya Jamāl al-Dīn!" Prof. Dr. Hamka, Said Jamaluddin Al-Afghany,h. 58-60.

51Dikutip dari Nurcholish Madjid, Tradisi Islam, h. 126-127; sumber aslinya: Hamka, Mengembalikan Tasawuf Ke Pangkalnya,Jakarta: Pustaka Panjimas, 1973, h. 40-41.

52Prof. Dr. Hamka, Pelajaran Agama Islam, h. 69-70.

53Ibid., h. 71.

${ }^{54}$ Ibid., h. 73.

${ }^{55}$ Nurcholis Madjid, Tradisi Islam, h. 131-132.

56Lebih jauh lihat Hamka, Prinsip dan Kebijaksanaan Da'wah Islam, Jakarta: UMMINDA, 1982, h. 198-213. 


\section{DAFTAR PUSTAKA}

Aceh, Abu Bakar, Pengantar Sejarah Sufi dan Tasawwuf, Solo: Ramadhani, 1993.

Ahmad, Abdul-FattahSayyid,Tasawuf antara Al-Ghazali dan Ibnu Taimiyah, penerj. Muhammad Muchson Anasy, Jakarta: Khalifa, 2005.

Arberry, A.J., Sufism: An Account of the Mystics of Islam, London: George Allen and Unwin Ltd, 1950.

Azra, Azyumardi, Historiografi Islam Kontemporer: Wacana, Aktualitas dan Aktor Sejarah, Jakarta: Gramedia, 2002.

Azra, Azyumardi, Jaringan Ulama Timur Tengah dan Kepulauan Nusantara Abad XVII dan XVIII: Melacak Akar-akar Pembaruan Pemikiran Islam di Indonesia, Bandung: Mizan, 1994.

Azra, Azyumardi, Renaisans Islam Asia Tenggara: Sejarah Wacana \& Kekuasaan, Bandung: Remaja Rosdakarya, 1999.

Baghdādī, Jamāl al-DīnAbū al-Faraj `Abd al-Raḥmān ibn Jawzī, Talbīs Iblīs, Kairo: Idārat al-Ṭibā'at al-Munīrīyah, 1368 H.

Dewan Redaksi Ensiklopedi Islam, Ensiklopedi Islam, Vol. IV, Jakarta: PT. Ichtiar Baru van Hoeve, 2002.

Fathurahman, Oman,dan Jajat Burhanuddin, "Tradisi dan Wacana Intelektual Islam Indonesia", artikel diakses dari http://naskahkuno.blogspot.com/2007/07/neo-sufismeghazalian-abdussamad-al.html.

Hamka, Mengembalikan Tasawuf Ke Pangkalnya, Jakarta: Pustaka Panjimas, 1973, h. 40-41.

Hamka, Pelajaran Agama Islam, Jakarta: Bulan Bintang, 1992.

Hamka, Prinsip dan Kebijaksanaan Da'wah Islam, Jakarta: UMMINDA, 1982.

Hamka, Said Jamaluddin Al-Afghani: Pelopor Kebangkitan Muslimin, Jakarta: Bulan Bintang, 1981.

TEOLOGIA, VOLUME 24, NOMOR 2, JULI-DESEMBER 2013 
Hodgson, Marshal G.,The Venture of Islam, Vol. III, Chicago: Chicago Univesiry Press, 1974.

Johns, A. H., "Sufism as a Category in Indonesia Literature and History", JSEAH, 2, II,1961.

Madjid, Nurcholish, Islam Agama Peradaban: Membangun Makna dan Relevansi Doktrin Islam Dalam Sejarah, Jakarta: Paramadina, 1995.

Madjid, Nurcholish, Islam Agama Peradaban: Membangun Makna dan Relevansi Doktrin Islam Dalam Sejarah, Jakarta: Paramadina, 1995.

Makdisi, George, "Ibn Taimiya: a Sufi of the Qādiriya Order", American Journal of ArabiStudies, AJAS 11974.

Makdisi, George, Religion, Law and Learning in Classical Islam, Hampshire and Vermont: Variorum, 1991.

Masyharuddin, PemberontakanTasawuf: Kritik Ibn Taimiyah atas Rancang Bangun Tasawuf, Surabaya: JP Books-STAIN Press Kudus, 2007.

Meier, Fritz, "Des saubersteuber die vorbesstimmung. Ein Stuck Ibn Taymiyyah", Saeculum 32 1981, h. 74-89.

Nasution, Harun, Pembaharuan Dalam Islam: Sejarah Pemikiran dan Gerakan, Jakarta: Bulan Bintang, 1992.

Rahardjo, M. Dawam, Intelektual, Intelegensia dan Perilaku Politik Bangsa: Risalah Cendekiawan Muslim, Bandung: Mizan, 1993.

Rahman, Fazlur, "Revival and Reform", dalam P. M. Holt et.al, The Cambridge History of Islam, Vol. II, 1970.

Rahman, Fazlur, Islam, edisi II, Chicago: University of Chicago Press, 1979.

Ramadhan, Sa'id, Al-Rūhanīyat Al-Ijtimā'`̄̄yahfī Al-Islām,Damaskus: tp, 1965.

Sa'ād, Al-Ṭablawī Maḥmūd, al-Tașawwuffi Turāś Ibn Taimiyah, Kairo: T.p., 1984. 
Shihab, Alwi, Membendung Arus: Respons Gerakan Muhammadiyah Terhadap Penetrasi Misi Kristen di Indonesia, Bandung: Mizan, 1998.

Sirriyeh, Elizabeth,Sufis and Anti-Sufis: The Defense, Rethinking and Rejection of Sufism in the Modern World, Richmond, Surrey: Curzon Press, 1999.

Syukur, Amin, Zuhud di Abad Modern, Yogyakarta: Pustaka Pelajar, 1997.

Wahid, Abdurrahman, "Benarkah Buya Hamka seorang Besar?", dalam Nasir Tamara, Buntaran Sanusi dan Vincent Djauhari (peny.), Hamka di mataUmat, Jakarta: Sinar Harapan, 1983. 